\title{
Report on the International Workshop on the Integration of Islamic Studies into Liberal Arts Curricula
}

\section{Brannon M. Wheeler}

On March 6-7, 1998 the incipient program in Comparative Islamic Studies at the University of Washington (UW) hosted an international workshop on the Integration of Islamic Studies into Liberal Arts Curricula. This workshop was sponsored by the Department of Near Eastern Languages and Civilization, the Walter Chapin Simpson Center for the Humanities, the Henry M. Jackson School for International Studies, the Comparative Religion Program, the Middle East Studies Program, and the South Asian Studies Program.

\section{Aims of the Workshop}

The general aim of the workshop, discussing the integration of Islamic studies into liberal arts curricula, can be divided into three areas. First, the workshop brought together about forty teachers and scholars, about twenty from the UW and twenty from across the United States and Canada. Most of these participants were professors teaching Islamic Studies or related disciplines at private and public colleges and universities, although some secondary-level teachers also participated. The disciplines represented ranged from religion, art history, geography, ethnomusicology, history, comparative literature, women's studies, anthropology, biblical studies, and political science. This meeting allowed for open communication and the exchange of ideas among scholars who are otherwise separated from one another by institutional boundaries. 
Second, the workshop aimed to address substantive issues facing those who teach Islamic studies within a more general liberal arts context. In particular, participants discussed the background and development of Islamic studies in liberal arts curricula, the building of programs in Islamic studies, and some of the theories and methods involved in the teaching of Islamic studies. Each session was designed to encourage wide-ranging discussion relating not only to pedagogical theories, but specifically to the sharing of actual experiences from teaching Islamic studies courses and administering Islamic studies programs.

Third, the workshop was designed as a means to initiate ongoing discussion and future developments within Islamic studies. The workshop coincided with the early stages of establishing a concentration in comparative Islamic studies at the UW, supported by close to thirty faculty members, various interdisciplinary programs, and some of the best resources in North America for the study of languages related to Islamic studies. Another initiative sparked by the workshop is the construction of an electronic database, with a biannual bulletin, devoted to resources for the integration of Islamic studies into liberal arts curricula. Most importantly, participants planned for future workshops, ones that would provide opportunities to include the contributions of Islamic studies specialists from regional institutions in the Middle East, South Asia, and Southeast Asia. A second workshop is now being planned for the spring of 2000 .

\section{Workshop Program}

The workshop took place over a period of two days on the campus of the UW in Seattle, though one of the more valuable aspects of the workshop was the opportunity to continue discussions over meals and outside the regular confines of the classroom and university buildings. In all, there were thirteen presentations spread over four sessions, each two hours in length, with two sessions on each day of the workshop. The presentations were purposefully informal, not stressing research and theorizing but raising questions and proposing some working solutions from the different experiences of all the participants. Each contributor was given roughly thirty minutes, with ten minutes to introduce issues and twenty minutes for discussion of these issues.

Session 1: History of Islamic Studies in Liberal Arts Curricula. This first session focused on the institutional developments and pedagogical background to the current role of Islamic studies. The session was moderated by Eugene Webb, professor and director of European studies at the UW.

A. Kevin Reinhart, Professor of Religion at Dartmouth College, spoke on "A 'Qualified' Success: The Training of Teachers of Islam in the 
Liberal Arts." Professor Reinhart argued that Islamic studies has not been well-integrated into the more general context of the liberal arts, nor into the academic study of religion. He began by pointing out that only roughly 20 percent to 30 percent of the departments of religion in North America have faculty positions in Islamic studies. In many cases, a faculty member with expertise in another area, such as Judaism or Indian religions, is responsible for teaching Islam. According to Professor Reinhart, this is in part due to the lack of adequate emphasis on the liberal arts in graduate programs that specialize in training Islamists and is especially the case with area studies programs. Professor Reinhart also faults those who are currently in teaching and research positions for not using Islamic studies to engage more general theory, though Islamic studies is ahead of other even more insulated specializations.

Jane McAuliffe, professor of Islamic studies at the University of Toronto, spoke on "Teaching Islam in the Multicultural Classroom." Professor McAuliffe spoke about the present religioethnic diversity in the classrooms of large, urban universities in North America. With an undergraduate population at the University of Toronto that is now over 5,096 from West, South, and East Asian backgrounds, courses in Islam tend to attract predominantly Muslim participation, a significant change from as recently as ten to fifteen years ago. Such shifts in classroom demographics raise multiple concerns and challenges. Student and community expectations can sometimes clash with the prevailing postEnlightenment mindset of much of the academic world. Yet shifting expectations within the academy, presented through such relatively new disciplines as women's studies, African-American studies, and postcolonial studies, when combined with this change in classroom demographics, are reopening some of the cherished constructs of the contemporary field of religious studies.

Martin S. Jaffee, professor of comparative religion at UW, spoke on, "Teaching Jewish Studies: A Comparative Case." As a comparison with the development of Islamic studies in Europe and North America, Professor Jaffee outlined three main models of Jewish studies. The religious studies model, seeks to develop a more nuanced general theory of religion by integrating Jewish examples into categories that are otherwise flawed because they were designed from a Christian perspective to deal with colonized peoples. A cultural studies model, which Professor Jaffee associates with the work of Marshall Hodgson in Islamic studies, seeks to de-essentialize "Jewish" by applying social science disciplines to examples from Judaism. A third model is the identity and politics model, which emphasizes the Jewish survival in a hostile environment. On the basis of these models, Professor Jaffee suggested that the attempts of Wissenschaft des Judentums to integrate Jewish culture into 
the high culture of Europe might offer some insight into the history of Islamic studies.

Zayn Kassam, assistant professor of religion at Pomona College, spoke on "Muslim Women through Literature." Professor Kassam presented the workshop participants with some of her own strategies in integrating Islamic studies into the curriculum, emphasizing that she is the only full-time Islamist on the campus of the six Claremont Colleges. One way she has integrated Islamic studies is by offering courses in more traditional fields or under more generic rubrics such as comparative literature or women's studies. She also showed how courses in Islamic studies can be used well to respond to the diverse breadth requirements used by most liberal arts curricula. Because many Islamists are the only source of expertise in Islam on campus, Professor Kassam stressed the importance of giving guest lectures and team teaching courses in which the contribution of Islamic studies can be made more evident.

Session 2: Teaching Islamic Studies. Unlike the other sessions, Session 2 was open to the public at large and drew an audience of about 150 people, most of whom were undergraduates at the UW interested in Islamic studies. Because of this format, there were only two speakers, both of whom were given forty-five minutes to talk and fifteen minutes each for discussion. This session was followed by a reception during which many students were able to speak further with all of the workshop participants. Session 2 was moderated by Brannon Wheeler, assistant professor of Islamic studies at the UW.

Carl Emst, professor and chair of religious studies at the University of North Carolina at Chapel Hill, spoke on the "Study of Islam and the Study of Religion." Professor Ernst argued that, since the publication of Charles Adams's well-known article in 1973, the relationship of the study of Islam to the study of religion has improved but still needs further work. In particular, Professor Ernst pointed out that twenty-five years ago, the field seemed ignorant of many of the issues that are important today. Likewise, in the past twenty-five years, the field of religion has evolved away from its bias toward the archaic and an overriding Eurocentrist outlook on certain methods and categories. According to Professor Ernst, these changes have allowed for more cross-disciplinary inquiry and a more sophisticated understanding of the connection between Islamic studies and the study of religion. The main problem still facing Islamic studies, according to Professor Ernst, is the gap between specialized graduate training focused on a small audience of experts and the need for more generalized and popular information on Islam.

Bruce Lawrence, professor and chair of religion at Duke University, spoke on "Regional Foci in the Representation of Islam: The Asian Case." Maintaining a distinction between Islam and Islamic civilization, Professor Lawrence stressed the significance of recognizing that Islamic 
civilization is more Asian than Arab and more Persian than Arabic. $\mathrm{He}$ outlined distinctive Asian social pattems such as a militarized society and autocratic rule and issues such as the "circle of justice" and the "hierarchy of the saints" as being related to the development of Islamic civilization outside of the Arab Middle East. Professor Lawrence based many of his points on the insights of Marshall Hodgson, underlining how Hodgson's presentation of development and diversity illustrates how Islamic civilization can be used to teach more general historical and cultural notions.

Session 3: Program Building and Future Plans. The third session dealt with issues related to the planning and building of effective programs in Islamic studies and some of the theoretical concerns surrounding different administrative choices. The moderators for this session were Jere L. Bacharach, professor of history and director of the Jackson School for International Studies, and Scott Noegel, assistant professor of Near Eastern languages and civilization, both at the UW.

Anne H. Betteridge, executive director of the Middle East Studies Association (MESA) of North America and professor of anthropology at the University of Arizona, spoke on "Islamic Studies in MESA." Professor Betteridge surveyed some of the ways in which Islamic studies have been represented in MESA since its inception in 1966 and emphasized how Islamic studies is becoming increasingly evident. In terms of MESA members, only a small proportion (less than 3 percent in the 1970 s and 1980s) identified themselves with religion or Islamic studies, though since 1996 more than 8 percent of members identified themselves as specialists in Islamic studies. On average, close to 20 percent of the papers and panels at the MESA annual meetings have been and continue to be related to Islamic studies (including Islamic history). Of the eigthteen scholars invited as part of the Ford Foundation Grant from 1975 to 1979 , only one was in Islamic studies. Since 1986, nine of the keynote speakers invited to the annual MESA meetings have been specialists in Islamic studies. Professor Betteridge also emphasized that since the 1976 publication of The Study of the Middle East (edited by L. Binder), the university programs in Islamic Studies have increased threefold, and certain related disciplines have seen even more dramatic increases.

Ahmet Karamustafa, professor of Islamic studies at Washington University in St. Louis, spoke on "The Pre-modern/Modern Divide in Teaching Islamic Studies." Professor Karamustafa emphasized that many programs and courses on Islam fail to distinguish (or utilize a false distinction) between modemity and premodemity. He argued, in particular, that facile views of the Shari'ah, reifying a classical ideal, have little bearing on contemporary legal practices. Likewise, the tendency to romanticize religion ignores its temporal dimension and shows no sense 
of how Islam, like other religions, is challenged by modernity. Echoing points made by earlier participants, Professor Karamustafa stressed the importance of teachers of Islamic studies showing Muslims as agents rather than simply dismissing them by assigning them to a previous age. Professor Karamustafa also made a persuasive case for the use of Islamic civilization as a case study for teaching about modernity as a generic concept.

Carl Ernst, Bruce Lawrence, and Richard C. Martin each discussed aspects of "Building Islamic Studies Programs" from their different experiences in establishing the Carolina, Duke, Emory Consortium for the Study of Islam (CDESI) program among their respective universities. Each of the contributors presented an overview of the history of the development of the Islamic studies programs at their three institutions. Professors Ernst and Lawrence explained that their programs had developed with particular emphasis on South Asia, including a series of Rockefeller fellowships from 1994 to 1997 on South Asian Islam and the Muslim world. Professor Martin indicated that the faculty at Emory draws on people in law, Near Eastern languages and civilizations, art history, and religion, among others. All three contributors stressed the value of a decentered approach, not creating a separate faculty for Islamic studies but leaving faculty members in their respective departments to contribute to an interdisciplinary concentration. The agreement among these three institutions includes both the exchange of graduate students and the exchange of faculty.

Session 4: Theory and Methods of Teaching Islamic Studies. The final session was intended as a forum for experimental ideas, the presentation of particular cases as examples for other courses, and the raising of some difficult to answer theoretical and methodological questions. The moderators of this session were Ahmad Karimi-Hakkak, professor of Persian language and literature in the Department of Near Eastern Languages and Civilization, and Daniel C. Waugh, associate professor of history, both at the UW.

Jonathan E. Brockopp, assistant professor of Islamic studies and chair of religion at Bard College, spoke on the "Political and Theological Aspects of Teaching Islam." Touching on some of the same points raised by Professors McAuliffe and Zayn Kassam, Professor Brockopp addressed the issue of advocacy in the classroom. He argued that Islamic studies is not dissimilar to gender studies and critical race theory in which students are exposed to discourses subversive to the dominant academic paradigms. As a major world religion, however, Islam may not require the same tolerance of advocacy speech given to these other subjects. Professor Brockopp further pushed participants to consider that in so far as theology is the knowledge and ability to manipulate sacred texts, the teacher of Islamic studies is doing theology in the classroom. 
This is particularly evident in the choices instructors make in having students read certain classical Qur'an commentaries or more contemporary revisionist scholarship. For Professor Brockopp, the classroom should be acknowledged as a political space, in which instructor and students are challenged to take account of and justify the power dynamics which accompany their varying positions and interpretations.

Richard C. Martin, professor of Islamic studies and chair of religion at Emory University, spoke on "Understanding Islam through Comparative Theology." Professor Martin argued that students are not satisfied with a more simplistic overview of such "essentials" as the "five pillars" and the "four orthodox law schools." Recent trends in both Islamic studies and in pedagogical theory more generally have moved away from an essentialist position to look at subjects from the more problematic periphery. Drawing upon the particular case of juxtaposing the notion of the "created Qur'an" with comparable concepts in Buddhism and Christianity, Professor Martin exemplified how such a problematic issue can be used to teach students about Islam. He also explained the benefit of a more decentered approach in allowing students to get inside some of the difficult issues facing Muslims and how these are analogous to the conceptual issues facing the student of religion.

Scott B. Noegel, assistant [rofessor of Near Eastern languages and civilization at the UW, spoke on "Non-traditional Teaching Technologies." Professor Noegel commented upon the favorable current classroom sentiment toward technology and suggested several possible ways to apply new technology for instructional and departmental outreach purposes. Among the applications discussed for the classroom were the artistic recreation of foreign language texts onto video with English subtitles (Professor Noegel used as an example an ancient Akkadian text "The Descent of Ishtar" which he produced); the use of video streaming technologies for language learning and video display; the use of multimedia presentations in the classroom; the creation of student monitored discussion lists tailored for specific classes; and the benefits of assigning to students the creation of html (World Wide Web) formatted research papers and resource sites. Professor Noegel also called for a university-wide text and image data base that could be integrated with the Web and CD-ROM technology, and he underscored the importance of networking, promoting, and updating departmental Web sites on the Internet.

Tazim R. Kassam, assistant professor of Islamic studies and South Asian religions at The Colorado College, spoke on "Linguistic, Interdisciplinary and Cultural Conundrums of Teaching Islam." Professor Kassam noted that Islam is frequently presented as a reified, monolithic entity whereas, in fact, it is an evolving civilization of very diverse cultural, racial, and geographic dimensions. Typically, Islam is taught within departments of religion, political science, or Middle 
Eastern studies. Each discipline constructs Islam in terms of its own bias and modes of discourse. Thus, when taught as a religion, Islam is defined primarily within a formulaic ritual, theological, and legal framework divorced from any specific cultural and historical roots. On the other hand, political approaches to Islam often ignore the aesthetic, philosophical, and spiritual aspects of Islamic cultures. Professor Kassam suggests that the very heterogeneity of the Islamic world creates linguistic, interdisciplinary, and cultural conundrums in the classroom because even basic terms such as "faith," "ritual," submission," "duty," "authority," and "justice" have significations that are divergent and even contrary within Islamic contexts as well as within scholars' usage and students' understanding of these terms. Hence, she finds that a key component in teaching students about Islamic cultures and civilization becomes the deconstruction of differing language systems and the critical analysis of social constructions of meaning.

\section{Conclusions}

By all accounts, the workshop and the discussions it initiated were a great success. The continuation of these discussions, but more importantly, the widening of the discussions to include more voices from different perspectives, is imperative for the continued integration of Islamic studies into liberal arts curricula. As the numbers of Muslims in North America continue to increase and Islam continues to be a significant force in the world, the need for a more integrated approach to the study of Islam becomes more important. This integration must be open to a wide variety of approaches, and it should facilitate better cooperation and coordination among scholars in the West and in more traditional Islamic institutions in the Middle East, South Asia, and Southeast Asia. It is this improved communication among scholars in the Islamic world and scholars studying the Islamic world in the West that must characterize any further discussion of how Islamic studies can contribute to a more general educational curriculum. 